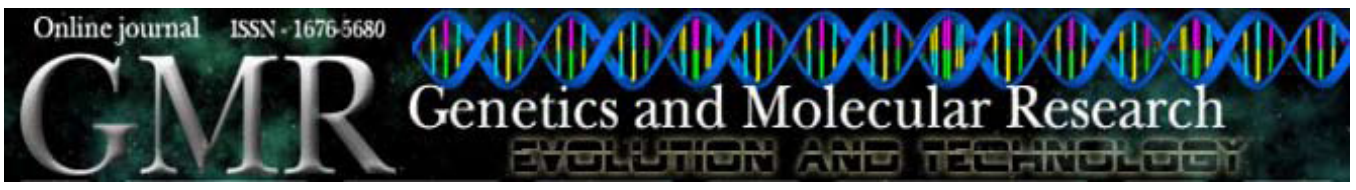

\title{
Influence of Chinese breeds on pork quality of commercial pig lines
}

\author{
A.S.M. Cesar ${ }^{1}$, A.C.P. Silveira ${ }^{1}$, P.F.A. Freitas ${ }^{1}$, E.C. Guimarães ${ }^{1}$, \\ D.F.A. Batista ${ }^{1}$, L.C. Torido ${ }^{1}$, F.V. Meirelles $^{2}$ and R.C. Antunes ${ }^{1}$ \\ ${ }^{1}$ Programa de Pós-Graduação em Ciências Veterinárias, Faculdade de Medicina \\ Veterinária, Universidade Federal de Uberlândia, Uberlândia, MG, Brasil \\ ${ }^{2}$ Departamento de Ciências Básicas, Faculdade de Zootecnia e Engenharia de \\ Alimentos, Universidade de São Paulo, Pirassununga, SP, Brasil \\ Corresponding author: A.S.M. Cesar \\ E-mail: aline_cesar@yahoo.com.br
}

Genet. Mol. Res. 9 (2): 727-733 (2010)

Received December 20, 2009

Accepted January 30, 2010

Published April 20, 2010

DOI 10.4238/vol9-2gmr733

\begin{abstract}
We compared carcass and meat quality of pigs from the same sire line and two different dam lines, one that included Chinese breeds and one that did not. Line A consisted of 1/4 Landrace, 1/2 Large White, 1/8 Chinese breeds (Meishan, Fengjing, Jiaxing), and 1/8 Large White, Duroc and Pietrain, and line B consisted of 1/2 Large White and 1/2 Pietrain. The animals $(\mathrm{N}=144)$ were slaughtered at a live weight of $108 \mathrm{~kg}$. Backfat thickness, percentage of lean meat, $\mathrm{pH} 24 \mathrm{~h}$ after slaughter, meat color, percentage of drip loss, and percentage of intramuscular fat were measured and compared using analysis of variance in a completely randomized design; the BioEstat 5.0 test was applied for the comparison of means at a significance level of 5\% for all analyses. Backfat was significantly lower for line A $(12.78 \mathrm{~mm})$ than for line B $(15.90 \mathrm{~mm})$. The $\mathrm{pH}$ measured 24 $\mathrm{h}$ after slaughter was significantly lower in line A (5.68) compared to line B (5.84). Percent lean meat was significantly higher for line A (61.21\%) compared to line B (59.72\%). Percentage drip loss was significantly higher in line A $(2.73 \%)$ than in line B (2.23\%). Percentage intramuscular fat and meat color were not significantly different between the lines. The inclusion of Chinese breeds produced a higher percentage of lean meat and
\end{abstract}


reduced fat thickness, along with increased heterosis, which are important characteristics for breeding programs.

Key words: Pork; Breed; pH; Muscle; Drip loss

\section{INTRODUCTION}

Since the domestication of pigs, humans have played an important role in the selection of higher genetic potential animals, and for several decades, many authors have focused their studies on describing the most important swine production characteristics all over the world (Young 1992; Newcom et al., 2004; Zhang et al., 2007).

Domestic pigs are descendants of the wild boar Sus scrofa, domesticated in Europe, and of the Sus vitattus species, domesticated in Asia (Fang and Andersson, 2006), each one showing specific phenotypic and genotypic characteristics, regarding production and reproduction. In the 18th century, there was an intense use of Asian breeds in lines with typical European white breeds. This introduced features such as lighter bones, early fat deposition, prolificacy, and thicker back fat, less hair and, in general, a better meat quality. In the 1960's, the first genetic improvement companies appeared, and they were mainly responsible for the creation of hybrids and the so-called synthetic or commercial lines, originating modern pig production (Porter, 1993). There was then a possibility of choice of a line or breed, which had a genetic profile that would meet specific consumer markets and their respective production costs.

With great potential for opening new markets such as Japan, European Union, United States, and Mexico (ABIPECS, 2007), Brazil needs to rethink its marketing purpose, by producing quality, which requires genetic changes in animals. These markets have different quality requirements, such as darker meat with more marbling, attributes that the Chinese breeds can offer in addition to better reproductive traits.

Thus, the hypothesis of this study was that carcass and meat quality would be different between the dam lines studied, since one of them was formed by Chinese breeds, Meishan, Fengjing and Jiaxing. The objective of this study was to compare the carcass and meat quality of two dam lines $\mathrm{A}$ and $\mathrm{B}$.

\section{MATERIAL AND METHODS}

\section{Animals and management}

This study compared two dam lines A and B. The protocol for this study was approved by the Ethics Committee of the Universidade Federal de Uberlândia. The right side of 144 pig carcass was used for the same sire line formed by 1/4 Pietrain, 1/4 Large White, 1/4 Duroc, and 1/4 Hampshire, with 72 animals from the dam line A (1/4 Landrace, 1/2 Large White, 1/8 Chinese breeds (Meishan, Fengjing, Jiaxing), and 1/8 Large White, Duroc and Pietrain) and 72 animals of the dam line B (1/2 Large White and 1/2 Pietrain). All animals in this study were genotyped for the halothane gene, resulting in $100 \%$ of homozygote NN.

All animals were raised on finishing farms in the southern region of Brazil. The sheds had mechanical ventilation and the foundation was concreted with slotted floor; pigs were housed at $0.40 \mathrm{~m}^{2}$ /animal. The animals were finished with $14.3 \%$ protein, $0.82 \%$ lysine and $3386 \mathrm{kcal}$ metab- 
olizable energy $/ \mathrm{kg}$. When the average weight of the animals reached $108 \mathrm{~kg}$, they were transported in appropriate trucks and kept in stalls for about $12 \mathrm{~h}$ with access to fresh water before slaughtering.

\section{Slaughter and measures of carcass and meat quality}

All animals were slaughtered on the same day under the same pre-slaughter conditions. Pigs $(\mathrm{N}=144)$ were weighed immediately prior to slaughter and harvested using standard procedures. The slaughter procedures were performed according to the guidelines of the Brazilian Federal Inspection Service. Carcasses were placed in a cooler at $4^{\circ} \mathrm{C}$. After $24 \mathrm{~h}$ in the cold room, $\mathrm{pH}$ was measured in the semimembranous muscle using a digital $\mathrm{pH}$ meter (model Testo 205) with a glass electrode. Backfat thickness (BF) was measured at the last lumbar vertebra over the shank. To calculate the percentage of lean meat (LM\%), the following formula was used: $\mathrm{LM} \%=$ $67.31240+0.47691 \times$ BF measurement (mm) (Antunes et al., 2002). The carcass was boned and a sample of approximately $100 \mathrm{~g}$ of the semimembranous muscle was collected for analysis of meat color, percentage of drip loss (DL\%) and percentage of intramuscular fat (IMF\%). Color was assessed in a room at $15^{\circ} \mathrm{C}$, where the samples were allowed to stand for $30 \mathrm{~min}$ for oxygenation of the surface according to the Japanese Pork Color Standards (JPCS) (Tan et al., 2000) with six color classes from 1 to $6(1=$ pale, $6=$ very dark $)$. The meat samples with values of 2.5 or higher were considered to be normal, and the meat samples with values less than 2.5 were considered to be pale, soft and exudative. The analysis of DL\% was performed according to Berg (2000) and the IMF\% measurement followed the ether extract analysis described by AOAC (1996).

\section{Statistical design and analysis}

The study of meat quality characteristics from different lines of swine was analyzed according to the following model: $\mathrm{Y}_{\mathrm{ij}}=\mu+\mathrm{C}_{\mathrm{i}}+\varepsilon_{\mathrm{ijk}}, \mathrm{Y}_{\mathrm{ij}}$ is the BF (mm), LM\%, pH of $24 \mathrm{~h}$, color, DL \% and IMF\%, where: $\mu$ is the certain characteristic average; $\mathrm{C}_{\mathrm{i}}$ is the line effect, and $\varepsilon_{\mathrm{ijk}}$ is the residual effect. Analysis of variance in a complete randomized design was performed, and the Tukey test was applied to compare means. The BioEstat 5.0 program (Ayres et al., 2007) was used in the study, and the 5\% significance level was applied to all analysis.

\section{RESULTS}

For some measures of carcass and meat quality, significant differences were observed as the effects of line (Table 1$). \mathrm{pH}$ measured $24 \mathrm{~h}$ after slaughter was significantly $(\mathrm{P}<0.01)$ lower in line A (5.68) compared to line B (5.84).

\begin{tabular}{|c|c|c|c|}
\hline Characteristic & Dam line A & Dam line B & $P$ \\
\hline $\mathrm{LM} \%$ & 61.2 & 59.7 & $<0.01$ \\
\hline $\mathrm{pH}$ & 5.68 & 5.84 & $<0.01$ \\
\hline DL\% & 2.7 & 2.2 & $<0.05$ \\
\hline $\mathrm{IMF} \%$ & 2.0 & 2.0 & 0.7521 \\
\hline Color & 2.8 & 2.8 & 0.5374 \\
\hline Fat thickness (mm) & 12.8 & 15.9 & $<0.01$ \\
\hline
\end{tabular}


$\mathrm{BF}(\mathrm{mm})$ was significantly $(\mathrm{P}<0.01)$ lower for line A $(12.78 \mathrm{~mm})$ than for line $\mathrm{B}$ $(15.90 \mathrm{~mm}) . \mathrm{LM} \%$ was observed to be significantly $(\mathrm{P}<0.01)$ higher for the dam line A (61.21\%) compared to line B $(59.72 \%)$.

DL\% was higher for line A (2.73\%) compared to line B (2.23\%), with this difference being statistically significant $(\mathrm{P}<0.01)$. As for the characteristics IMF\% and meat color, there was no statistical difference $(\mathrm{P}>0.05)$ between lines.

\section{DISCUSSION}

Animals that carry the "acidic meat gene" or Rendment Napole (RN) in its genome have increased levels of glycogen in the muscles, which means a potential post-mortem glycolytic increase. The increase in glycogenolysis post-mortem results from lactic acid accumulation, which can lower $\mathrm{pH}$ in muscles down to 5.4. Normal $\mathrm{pH}$ values are considered to be 5.5 to 5.7 (Brewer et al., 2002). This gene normally occurs in purebreds or in Hampshire lines, and it is commonly maintained in swine populations because it is associated with weight gain and subcutaneous fat decrease (Leroy et al., 1996).

The $\mathrm{pH}$ of $24 \mathrm{~h}$ found in this study was 5.84 for line $\mathrm{B}$, which was significantly higher $(\mathrm{P}<0.01)$ than line A $(5.68)$ (Table 1) values within the appropriate range. Despite line A having the Hampshire breed, it did not show very low $\mathrm{pH}$ values, which could be expected in these animals meat because of their acidic meat gene. However, it could be enough to account for the observed difference between the lines. These findings agree with those of Brewer et al. (2002) and disagree with those of Nguyen et al. (2006) who did not find a significantly different $\mathrm{pH}$ of $24 \mathrm{~h}$ between high and low growth rate lines.

Very low $\mathrm{pH}$ levels result in low water holding capacity (WHC), and consequent protein denaturation and lower meat quality. Water is the major meat constituent representing approximately $75 \%$ of the meat weight, and is an essential quality parameter, both for industry and final consumer. Low WHC values may cause problems in processed meats for the industry, and problems in the fresh meat appearance for the consumer (den Hertog-Meischke et al., 1997). The main factors that affect WHC and thus drip loss are: genotype (HAL and RN genes), pre-slaughter management and stunning methods (Claeys et al., 2001; Schäfer et al., 2002). According to den Hertog-Meischke et al. (1997), other important feature that affects WHC is the predominant type of fiber in the muscle. Muscles with major amount of glycolytic fibers, also called white muscle fibers (fast contraction, type II A, anaerobic) have a lower WHC and a high pH drop rate after death (Lawrie, 2005), as well as a lower final pH. The semimembranous muscle evaluated in this study is a white muscle fiber type.

In this study, it was possible to demonstrate a $\mathrm{pH} /$ drip loss relationship, finding lower $\mathrm{pH}$ values and, thus, higher drip loss values in line $\mathrm{A}(2.7 \%)$ compared to line $\mathrm{B}(2.2 \%)$, a difference that was statistically significant (Table 1).

Many studies have shown differences between European and Chinese breeds regarding meat quality characteristics such as fat deposition, LM\%, loin eye area, and IMF\% (Hsieh et al., 1991; Young, 1992, 1998; Nii et al., 2005). These studies present, for example, Hampshire and Landrace breeds with lower BF and higher loin eye area than Meishan, Fengjing and Minzhu breeds (members of Taihu breed group, which are similar to each other).

Legault et al. (1985) compared pure breed Pietrain animals, Meishan x Pietrain and Jiaxing Black x Pietrain line, and observed heavier loins, legs and blades, and lower BF in 
Pietrain animals' belly. LM\% was 54.4, 45.6 and 45.7 in Pietrain, Meishan x Pietrain and Jiaxing Black x Pietrain carcasses, respectively.

Chinese breeds have an earlier carcass fat deposition, which reflects higher $\mathrm{BF}$ and $\mathrm{IMF} \%$ and, thus, a decrease in muscle (meat) percentage, which is often an undesirable characteristic regarding meat production in certain consumer niches, such as those where lean meat is preferred. However, these breeds have a high prolificacy and are rustic, which are characteristics equally important to meat production.

In this study, a lower LM\% and higher BF was expected in the line in which Chinese breeds (line A) took part, by comparing two lines. However, this was not observed since LM\% was significantly higher $(\mathrm{P}<0.01)$ and $\mathrm{BF}$ was significantly lower $(\mathrm{P}<0.01)$ in line A (inversely proportional) compared to line B (Table 1). These results may be due to the fact that line A had only $12.5 \%$ Chinese blood. On the other hand, the Large White present in line B, which is a hyperprolific breed with a higher content of fat in the carcass, may also have influenced this characteristic of line B. According to Watanabe et al. (1986), Giuffra et al. (2000) and Okumura et al. (2001), the Large White breed was influenced by Chinese breeds at the end of the 18th century. Besides, molecular biology studies in Large White breed clearly show an introgression of Asian breeds into European breeds, by the high proportion of mitochondrial DNA originating from Asia.

The Chinese breeds' influence over the white breeds, such as the Yorkshire (Large White), population in England, resulted in decreased age of slaughter from 18 to 9 months after birth or even less, besides lighter bones, less hair, and smaller heads and carcasses, yielding Large White lines with higher fat deposition, decreased growth rate and lower weight. According to Monin and Ouali (1991), Large White meat, in general, has better technological quality when compared to Landrace or Pietrain meat.

Muscle color is associated with the abnormalities pale, soft and exudative meat and dark, firm and dry meat. According to Japanese color standards for meat, a color level of 2.5 or higher is considered to be normal and lower than 2.5 is considered to be pale, soft and exudative meat. In this study, the color of the samples obtained for the two lines showed an average value of 2.76 for line A and 2.85 for line B (Table 1), being statistically equal values $(\mathrm{P}=0.5374)$ within the range considered normal, even though the semimembranous muscle, which was used in this study, has a great proportion of white fibers. Newcom et al. (2004), on the other hand, found significant differences in meat color, while assessing different breeds, including Berkshire, Duroc, Hampshire, Landrace, Poland China, and Yorkshire. They also used a 1 to 6 color scale. Berkshire and Duroc breeds had higher values on the 1 to 6 color scale (the same used in this study): 3.9 and 3.5, respectively, which were statistically equal. Yorkshire and Landrace breeds showed an average of 2.5. However, Edwards et al. (2003) found no differences between Duroc and Pietrain breeds in the color parameter measured by colorimetry.

\section{CONCLUSION}

In this study, we observed differences in carcass and meat quality between the two dam lines studied. The line that had Chinese blood showed a higher percentage of lean meat and lower fat thickness, which are important traits in commercial breeding programs. 


\section{IMPLICATIONS}

The use of Chinese breeds in swine genetic improvement programs depends fundamentally on the consumer market, which has two possible ways: one that demands more lean and inexpensive meat with lower quality (color, flavor, succulence), and the other that demands more fat and expensive meat, which probably has a better quality meat. Genetic programs should establish the purpose of their production and, with the aid of molecular biology techniques, develop the "suitable" pig. Besides quality characteristics, it is important to know that the Chinese breed's introduction in the maternal lines gives important prolificacy and rusticity in future commercial lines.

\section{ACKNOWLEDGMENTS}

\section{Research supported by CAPES.}

\section{REFERENCES}

Antunes RC, Pita FVC, Franco MM and Goulart Filho ELR (2002). The racial composition of the maternal line and the Hal genotype influence on the meat quality of the pigs slaughtered from 90 to $110 \mathrm{~kg}$ of weight live. Ars Vet. 18: 33-42.

AOAC (1996). Official Methods of Analysis of AOAC International. 16th edn. Vol. 2. AOAC Int., Arlington.

Associação Brasileira de Indústrias Processadoras e Exportadoras de Carne Suína (ABIPECS) (2007). Associação Brasileira de Indústrias Processadoras e Exportadoras de Carne Suína. Available at [http://www.Abipecs.com.br]. Accessed February 22, 2009.

Ayres M, Ayres M Jr, Ayres DL and Santos AS (2007). BioEstat 5.0. Aplicações Estatísticas nas Áreas das Ciências BioMédicas. Sociedade Civil de Mamirauá, Belém.

Berg E (Editor) (2000). Pork Composition and Quality Assessment Procedures. National Pork Producers Council and American Meat Science Association, Des Moines.

Brewer MS, Jensen J, Sosnicki AA, Fields B, et al. (2002). The effect of pig genetics on palatability, color and physical characteristics of fresh pork loin chops. Meat Sci. 61: 249-256.

Claeys E, De Smet S, Demeyer D, Geers R, et al. (2001). Effect of rate of pH decline on muscle enzyme activities in two pig lines. Meat Sci. 57: 257-263.

den Hertog-Meischke MJ, van Laack RJ and Smulders FJ (1997). The water-holding capacity of fresh meat. Vet. Q. 19: 175-181.

Edwards DB, Bates RO and Osburn WN (2003). Evaluation of Duroc- vs. Pietrain-sired pigs for carcass and meat quality measures. J. Anim. Sci. 81: 1895-1899.

Fang M and Andersson L (2006). Mitochondrial diversity in European and Chinese pigs is consistent with population expansions that occurred prior to domestication. Proc. Biol. Sci. 273: 1803-1810.

Giuffra E, Kijas JM, Amarger V, Carlborg O, et al. (2000). The origin of the domestic pig: independent domestication and subsequent introgression. Genetics 154: 1785-1791.

Hsieh CY, Rothschild MF and Christian LL (1991). Reproduction, growth and carcass performance of Chinese pigs and their crosses. Iowa State University Swine Research Reports, Ames, 23-26. ASL-855.

Lawrie RA (2005). Ciência da Carne. 6th edn. Artmed, Porto Alegre.

Legault C, Sellier P, Caritez JC, Dando P, et al. (1985). L'expérimentation sur le porc chinois en France. II: Performances de production en croisement avec les races européennes [Experiments with Chinese pigs in France. II. Productive performance in crosses in European breeds]. Genet. Sel. Evol. 17: 133-152.

Leroy P, Monin O, Elsen JM, Cortiez JC, et al. (1996). Effect of the RN Gene on Technological and Sensory Meat Quality in Linebred Pigs with Hampshire as Terminal Sire. In: 47th Annual Meeting of the European Association for Animal Production, 25-29 August 1996, Lillehammer.

Monin G and Ouali A (1991). Muscle Differentiation and Meat Quality. In: Developments in Meat Science (Ralston L, ed.). Elsevier Applied Science, London. 89-138.

Newcom DW, Stalder KJ, Baas TJ, Goodwin RN, et al. (2004). Breed differences and genetic parameters of myoglobin 
concentration in porcine longissimus muscle. J. Anim. Sci. 82: 2264-2268.

Nguyen NH, McPhee CP and Trout GR (2006). Responses in carcass lean pH at 24 hours post-mortem in lines of Large White pigs selected for growth rate on a fixed ration over a set time. Livest. Sci. 100: 84-90.

Nii M, Hayashi T, Mikawa S, Tani F, et al. (2005). Quantitative trait loci mapping for meat quality and muscle fiber traits in a Japanese wild boar x Large White intercross. J. Anim. Sci. 83: 308-315.

Okumura N, Kurosawa Y, Kobayashi E, Watanobe T, et al. (2001). Genetic relationship amongst the major non-coding regions of mitochondrial DNAs in wild boars and several breeds of domesticated pigs. Anim. Genet. 32: 139-147.

Porter V (1993). Pigs: A Handbook to the Breeds of the World. Cornell University, New York.

Schäfer A, Rosenvold K, Purslow PP, Andersen HJ, et al. (2002). Physiological and structural events post mortem of importance for drip loss in pork. Meat Sci. 61: 355-366.

Tan FJ, Morgan MT, Ludas LI, Forrest JC, et al. (2000). Assessment of fresh pork color with color machine vision. J. Anim. Sci. 78: 3078-3085.

Watanabe T, Hayashi Y, Kimura J, Yasuda Y, et al. (1986). Pig mitochondrial DNA: polymorphism, restriction map orientation, and sequence data. Biochem. Genet. 24: 385-396.

Young LD (1992). Effects of Duroc, Meishan, Fengjing, and Minzhu boars on carcass traits of first-cross barrows. J. Anim. Sci. 70: 2030-2037.

Young LD (1998). Survival, body weights, feed efficiency, and carcass traits of 7/8 White Composite and 1/8 Duroc, 1/8 Meishan, 1/8 Fengjing, or 1/8 Minzhu pigs. J. Anim. Sci. 76: 1550-1558.

Zhang S, Knight TJ, Stalder KJ, Goodwin RN, et al. (2007). Effects of breed, sex, and halothane genotype on fatty acid composition of pork longissimus muscle. J. Anim. Sci. 85: 583-591. 